\title{
Bibliography
}

The bibliography is in two parts: the first gives English-language publications, the second gives Korean publications.

\section{English-language publications}

Adorno, Theodor W., 'Scientific experiences of a European scholar in America', in Donald Feming and Bernard Bailyn (eds), The Intellectual Migration: Europe and America, 1930-60 (Cambridge, MA, Harvard University Press, 1969), pp. 338-70.

Adorno, Theodor W., The Cultural Industry: Selected Essays on Mass Culture, ed. J. M. Bernstein (London, Routledge, 1991).

Adorno, Theodor W. and Max Horkheimer, Dialectic of Enlightenment, trans. John Cumming, new edn (London, Verso, 1979).

Agger, Ben, Cultural Studies as Critical Theory (London, Falmer Press, 1992).

Althusser, Louis, 'From capital to Marx's philosophy', in Althusser, Louis, and Étienne Balibar, Reading Capital, trans. Ben Brewster (London, NLB, 1970), pp. 11-69.

Althusser, Louis, 'The errors of classical economics', in Althusser, Louis, and Étienne Balibar, Reading Capital, trans. Ben Brewster (London, NLB, 1970), pp. 91-118.

Althusser, Louis, Lenin and Philosophy and Other Essays, trans. Ben Brewster (London, Monthly Review Press, 1977).

Althusser, Louis, 'Ideology and ideological state apparatuses', in Lenin and Philosophy and Other Essays, trans. Ben Brewster (London, Monthly Review Press, 1977), pp. 121-73.

Althusser, Louis, Essays on Ideology (London, Verso, 1984).

Althusser, Louis, For Marx, trans. Ben Brewster (London, Verso, 1996).

Althusser, Louis and Étienne Balibar, Reading Capital, trans. Ben Brewster (London, NLB, 1970).

An, Tae Sung, North Korea in Transition: From Dictatorship to Dynasty (Westport, Connecticut, Greenwood Press, 1983).

Anderson, Benedict, Imagined Communities (London, Verso, 1991). 
Andrew, J. Dudley, The Major Film Theories: An Introduction (London, Oxford University Press, 1976).

Andrew, J. Dudley, Concepts in Film Theory (Oxford, Oxford University Press, 1984).

Barrett, Michèle, The Politics of Truth: from Marx to Foucault (Cambridge, Polity, 1991).

Barthes, Roland, Mythologies, trans. Annette Lavers (London, Vintage, 1993).

Baudry, Jean-Louis, Ideological effects of the basic cinematographic apparatus', in Bill Nichols (ed.), Movies and Methods Volume II: An Anthology (Berkeley, University of California Press, 1985), pp. 531-42.

Bauman, Zygmunt, Hermeneutics and Social Science: Approach to Understanding (London, Hutchinson \& Co., 1978, repr. Gregg Revivals, 1992).

Benjamin, Walter, 'The work of art in the age of mechanical reproduction', in Illuminations, trans. Harcourt Brace Jovanovich (London, Cape, 1970), pp. 211-44.

Bennett, Tony et ah (eds), Culture, Ideology and Social Process (London, Batsford, 1981).

Bennett, Tony et ah (eds), Popular Culture and Social Relations (Milton Key nes, Open University Press, 1986).

Benton, Ted, The Rise and Fall of Structural Marxism: Althusser and his Influence (London, Macmillan Publishers, 1984).

Berger, Arthur A., Cultural Criticism (Thousand Oaks, Sage Publications, 1995).

Bhabha, Homi K., 'The other question: the stereotype and colonial discourse', The Sexual Subject: A Screen Reader in Sexuality (London, Routledge, 1992), pp. 312-31.

Bottomore, T. B., Class in Modern Society (London, George Allen \& Unwin, 1965).

Bourdieu, Pierre, Distinction: A Social Critique of the Judgement of Taste (Cambridge, MA, Harvard University Press, 1984).

Cahiers du Cinéma, (editors of) 'John Ford's Young Mr Lincoln, in Bill Nichols (ed.), Movies and Methods Volume I: An Anthology (Berkeley, University of California Press, 1976), pp. 493-529.

Chin, In-sook, A Classical Novel Ch'unhyangjon (Seoul, Korean Centre, International PEN, 1970).

Comolli, Jean-Louis and Jean Narboni, 'Cinema/ideology/criticism', in Bill Nichols (ed.), Movies and Methods Volume I: An Anthology (Berkeley, University of California Press, 1976), pp. 22-30.

Crapanzano, Vincent, 'Hermes' dilemma, the masking of subversion in ethnographic description', in James Clifford and George E. Marcus (eds), Writing Culture (Berkeley, University of California Press, 1986), pp. 51-76.

Cumings, Bruce, The Origin of the Korean War: Liberation and the Emergence of Separate Regimes, 1945-1947, vol. I (Princeton, Princeton University Press, 1990).

Cumings, Bruce, The Origin of the Korean War: The Roaring of the Cataract, 1947-1950, vol. II (Princeton, Princeton University Press, 1990). 
Cumings, Bruce, 'The corporate state in North Korea', in Hagen Koo (ed.), State and Society in Contemporary Korea (Ithaca, Cornell University Press, 1993), pp. 13-50.

Denzin, Norman K., Images of Postmodern Society: Social Theory and Contemporary Cinema (London, Sage Publications, 1991).

Dissanayake, Wimal (ed.), Colonialism and Nationalism in Asian Cinema (Bloomington, Indiana University Press, 1994).

Eagleton, Terry, Criticism and Ideology: A Study in Marxist Literary Theory (London, Routledge, 1976).

Fiske, John and John Hartley, Reading Television (London, Routledge, 1978).

Foucault, Michel, The History of Sexuality I: An Introduction, trans. Robert Hurley (London, Penguin Books, 1979).

Foucault, Michel, Michel Foucault: Power, Truth, Strategy, ed. Meaghan Morris and Paul Patton (Sydney, Fedal Publications, 1979).

Foucault, Michel, Discipline and Punish: The Birth of the Prison, trans. Alan Sheridan (London, Penguin Books, 1979).

Foucault, Michel, Power/Knowledge: Selected Interviews and Other Writings 1972-1977, ed. Colin Gordon, trans. Colin Gordon and others (New York, Harvester Press, 1980).

Foucault, Michel, 'Power and strategies', in Colin Gordon (ed.), Power/ Knowledge: Selected Interviews and Other Writings 1972-1977, trans. Colin Gordon and others (New York, Harvester Press, 1980), pp. $134-45$.

Foucault, Michel, Michel Foucault: Politics, Philosophy, Culture, ed. Lawrence D. Kritzman, trans. Alan Sheridan and others (London, Routledge, 1988).

Foucault, Michel, 'Critical theory/intellectual history', in Lawrence D. Kritzman (ed.), Michel Foucault: Politics, Philosophy, Culture, trans. Alan Sheridan and others (London, Routledge, 1988), pp. 17-46.

Foucault, Michel, 'Power and sex', in Lawrence D. Kritzman (ed.), Michel Foucault: Politics, Philosophy, Culture, trans. Alan Sheridan and others (London, Routledge, 1988), pp. 110-24.

Foucault, Michel, The Order of Things: An Archaeology of the Human Sciences (London, Routledge, 1989).

Gadamer, Hans-Georg, Truth and Method, trans. Willam Glen-Doepel (London, Seed \& Ward, 1989).

Geertz, Clifford, The Interpretation of Culture (London, Fontana, 1993).

Geertz, Clifford, Local Knowledge (London, Fontana, 1993).

Giddens, Anthony, The Class Structure of the Advanced Societies (London, Hutchinson, 1973).

Giddens, Anthony, 'The nations as power-container', in John Hutchinson and Anthony D. Smith (eds), Nationalism (Oxford, Oxford University Press, 1994), pp. 34-5.

Gledhill, Christine, 'Recent developments in feminist criticism in theory', in Gerald Mast and Marshall Cohen (eds), Film Theory and Criticism: Introductory Readings, 3rd edn (New York, Oxford University Press, 1985), pp. 817-45.

Gramsci, Antonio, Selections from the Prison Notebooks, ed. and trans. Quintín Hoare and Geoffrey No well-Smith (London, Lawrence \& Wishart, 1971). 
Gramsci, Antonio, Selections from Cultural Writings, ed. David Forgacs and Geoffrey Nowell-Smith, trans. William Boelhower (London, Lawrence \& Wishart, 1985).

Griffin, Roger, 'Nationalism', in Contemporary Political Ideologies (London, Pinter Publishers, 1993), pp. 147-68.

Hall, Stuart, The Hard Road to Renewal: Thatcherism and the Crisis of the Left (London, Verso, 1988).

Harvey, Sylvia (ed.), May 1968 and Film Culture (London, British Film Institute, 1978).

Heath, Stephen, 'Differences', in The Sexual Subject: A Screen Reader in Sexuality (London, Routledge, 1992), pp. 47-106.

Heywood, Andrew, Political Ideologies: An Introduction (London, Macmillan Press, 1992).

Hill, John, Sex, Class and Realism: British Cinema 1956-1963 (London, British Film Institute, 1986).

Hirst, Paul, 'Althusser and the theory of ideology', in On Law and Ideology (London, Macmillan, 1979), pp. 40-74.

Hobsbawm, Eric and Terence Ranger (eds), The Invention of Tradition (Cambridge, Cambridge University Press, 1992).

Horkheimer, Max, 'The latest attack on metaphysics', in Stanley Aronowitz (ed.), Critical Theory: Selected Essays, trans. Mettew O'Connell and others (New York, Herder and Herder, 1972), pp. 132-87.

Horkheimer, Max, 'Traditional and critical theory', in Stanley Aronowitz (ed.), Critical Theory: Selected Essays, trans. Mettew O'Connell and others (New York, Herder and Herder, 1972), pp. 188-243.

Howard, Michael, 'War and nations', in John Hutchinson and Anthony D. Smith (eds), Nationalism (Oxford, Oxford University Press, 1994), pp. 254-7.

Howells, Richard, 'The interpretation of popular culture as modern myth' (unpublished doctoral thesis, University of Cambridge, 1994).

Hutchinson, John, and Anthony D. Smith (eds), Nationalism (Oxford, Oxford University Press, 1994).

Inglis, Fred, Media Theory: An Introduction (Oxford, Blackwell Publishers, 1990).

Jameson, Frederic, Marxism and Form (Princeton, NJ, Princeton University Press, 1972).

Jameson, Fredric, 'Class and allegory in contemporary mass culture, Dog Day Afternoon as a political film (1979)', in Signatures of the Visible (London, Routledge, 1992), pp. 35-54.

Jameson, Fredric, 'Diva and the French socialism (1982)', in Signatures of the Visible (London, Routledge, 1992), pp. 55-62.

Johnston, Claire, 'Women's cinema as counter-cinema', in Bill Nichols (ed.), Movies and Methods Volume I: An Anthology (Berkeley, University of California Press, 1976), pp. 208-17.

Johnston, Claire, 'Towards a feminist film practice, some theses', in Bill Nichols (ed.), Movies and Methods Volume II: An Anthology (Berkeley, University of California Press, 1985), pp. 315-27.

Kellner, Douglas, Media Culture: Cultural Studies, Identity and Politics between the Modern and the Postmodern (London, Routledge, 1995). 
Kim, II Sung, 'On eliminating dogmatism and formalism and establishing Juche in ideological work: Speech to Party propaganda and agitation workers', 28 December 1955, in Kim II Sung Works 9: July 1954December 1955 (Pyongyang, Foreign Language Publishing House, 1982). pp. 395-417.

Kim, II Sung, 'Let us embody the revolutionary spirit of independence, selfsustenance and self-defence more thoroughly in all branches of state activities', 16 December 1967, in Kim II Sung Works 21 (Pyongyang, Foreign Language Publishing House, 1985), pp. 408-67.

Kim, Jong II, The Character and the Actor (Pyongyang, Foreign Language Publishing House, 1987).

Kim, Jong II, The Cinema and Directing (Pyongyang, Foreign Language Publishing House, 1987).

Koo, Hagen (ed.), State and Society in Contemporary Korea (Ithaca, Cornell University Press, 1993).

Koo, Hagen, 'Strong state and contentious society', in Hagen Koo (ed.), State and Society in Contemporary Korea (Ithaca, Cornell University Press, 1993), pp. 231-49.

Korean Film Export \& Import Corporation, Korean Film Art (Pyongyang, Korean Film Export \& Import Corporation, 1985).

Kuhn, Annette, Women's Picture: Feminism and Cinema, 2nd edn (London, Verso, 1994).

Leak, Andrew, Barthes: Mythologies (London, Grant \& Cutler, 1994).

Lee, Young-il and Young-chol Choe, The History of Korean Cinema, ed. Motion Picture Promotion Corporation, trans. Richard Lynn Greever (Seoul, Jimoondang, 1988).

Marx, Karl, Karl Marx: Selected Writings, ed. David McLellan (Oxford, Oxford University Press, 1977).

Marx, Karl, 'Preface to A Contribution to the Critique of Political Economy', in David McLellan (ed.), Karl Marx: Selected Writings (Oxford, Oxford University Press, 1977), pp. 388-92.

Marx, Karl and Frederick Engels, The German Ideology I \& III, ed. and trans. R. Pascal (New York, International Publishers, 1963).

Marx Karl and Frederick Engels, 'The communist manifesto', in David McLellan (ed.), Karl Marx: Selected Writings (Oxford, Oxford University Press, 1977).

Marx, Karl and Frederick Engels, On Literature and Art (Moscow, Progress Publishers, 1978).

Mast, Gerald and Marshall Cohen (eds), Film Theory and Criticism: Introductory Readings, 3rd edn (New York, Oxford University Press, 1985).

Mast, Gerald and Marshall Cohen, 'Film, psychology, society and ideology', in Gerald Mast and Marshall Cohen (eds), Film Theory and Criticism: Introductory Readings, 3rd edn (New York, Oxford University Press, 1985), pp. 669-74.

McLellan, David, Ideology, 2nd edn (Buckingham, Open University Press, 1995).

Mulvey, Laura, 'Visual pleasure and narrative cinema', Screen, 16:3 (1975), 6-18. 
Nichols, Bill (ed.), Movies and Methods Volume I: An Anthology (Berkeley, University of California Press, 1976).

Nichols, Bill, Ideology and the Image: Social Representation in the Cinema and Other Media (Bloomington, Indiana University Press, 1981).

Nichols, Bill (ed.), Movies and Methods Volume 11: An Anthology (Berkeley, University of California Press, 1985).

Palmer, Richard E., Hermeneutics: Interpretation Theory in Schleirmarcher, Dilthey, Heidegger and Gadamer (Evanston, IL, Northwestern University Press, 1969).

Parkin, Frank, Class Inequality and Political Order: Social Stratification in Capitalist and Communist Societies (Frogmore, Granada Publication, 1972).

Parkin, Frank, Marxism and Class Theory: A Bourgeois Critique (London, Tavistock, 1979).

Polan, Dana B., Towers of vision, visions of power', Camera Obscura: A Journal of Feminism and Film Theory, 18 (1988), 106-19.

Poulantzas, Class in Contemporary Capitalism, trans. David Ferbach (London, NLB, 1975).

Pollack, Griselda, 'What's wrong with "image of women”?', in The Sexual Subject: A Screen Reader in Sexuality (London, Routledge, 1992), pp. 135-45.

Pribram, E. Deidre (ed.), Female Spectators: Looking At Film and Television (London, Verso, 1988).

Rosenstone, Robert A., Visions of the Past: The Challenge of Film to Our Idea of History (Cambridge, MA, Harvard University Press, 1995).

Rayns, Tony, 'Korea's new wavers', Sight and Sound, 4:11 (1994), 22-5.

Said, Edward W., Orientalism: Western Conceptions of the Orient (London, Penguin Books, 1985).

Saudners, Peter, Social Class and Stratification (London, Routledge, 1990).

Scase, Richard, Class (Buckingham, Open University Press, 1992).

Screen Reader 1: Cinema/Ideology/Politics (London, Society for Education in Film and Television, 1977).

Short, K. R. M. (ed.), Feature Films as History (London, Croom Helm, 1981).

Silverman, Kaja, The Subject of Semiotics (Oxford, Oxford University Press, 1983).

Smith, Anthony D., Theories of Nationalism (London, Gerald Duckworth \& Company, 1971).

Sorlin, Pierre, The Film in History: Restaging the Past (Oxford, Basil Blackwell Publisher, 1980).

Spellerberg, James, 'Technology and ideology in the cinema', in Gerald Mast and Marshall Cohen (eds), Film Theory and Criticism: Introductory Readings, 3rd edn (New York, Oxford University Press, 1985), pp. 761-75.

Stam, Robert and Louise Spence, 'Colonialism, racism, and representation, an introduction', in Bill Nichols (ed.), Movies and Methods Volume II: An Anthology (Berkeley, University of California Press, 1985), pp. 632-49.

Standish, Isolde, 'Korean cinema and the new realism, text and context', in Wimal Dissanyake (ed.), Colonialism and Nationalism in Asian Cinema (Bloomington, Indiana University Press, 1994), pp. 65-89. 
Storey, John, An Introductory Guide to Cultural Theory and Popular Culture (Hertfordshire, Harvester Wheatsheaf, 1993).

Suh, Dae-Sook, Kim II Sung: The North Korean Leader (New York, Columbia University Press, 1988).

Suh, Jae-Jean, 'Theoretical revision of Juche thought and nationalism in North Korea', The Korean Journal of National Unification, 2 (1993), 7-29.

Telotte, J. P., Voices in the Dark: The Narrative Patterns of Film Noir (Urbana, University of Illinois Press, 1989).

Thompson, E. P., The Making of the English Working Class (London, Victor Gollancz, 1980).

Thompson, John B., Studies in the Theory of Ideology (Cambridge, Polity Press, 1984).

Thompson, John B., Ideology and Modern Culture: Critical Social Theory in the Era of Mass Communication (Cambridge, Polity Press, 1990).

Turner, Graeme, British Cultural Studies: An Introduction, 2nd edn (London, Routledge, 1996).

Vincent, Andrew, Modern Political Ideology, 2nd edn (Oxford, Blackwell Publisher, 1995).

Weber, Max, 'The nation', in John Hutchinson and Anthony D. Smith (eds), Nationalism (Oxford, Oxford University Press, 1994), pp. 21-5.

Williams, Linda (ed.), The Sexual Subject: A Screen Reader in Sexuality (London, Routledge, 1992).

Williams, Linda (ed.), Viewing Positions: Ways of Seeing Film (New Brunswick, Rutgers University Press, 1994).

Williams, Raymond, Marxism and Literature (Oxford, Oxford University Press, 1977).

Wilson, Rob, 'Melodramas of Korean national identity, from Mandala to Black Republic', in Wimal Dissanyake (ed.), Colonialism and Nationalism in Asian Cinema (Bloomington, Indiana University Press, 1994), pp. 90-104.

Zavarzadeh, Ma'sud, Seeing Films Politically (Albany, State University of New York Press, 1991).

\section{Korean publications}

An, Chonghwa, Hariguk Yŏnghwa Ch'ŭngmyŏn Pisa (Undisclosed Korean Film History) (Seoul, Ch'unch'ugak, 1962).

Board of National Unification, Pukhan-ŭi Yorrigŭk Yŏnghwa (North Korean Theatre Drama and Film) (Seoul, Board of National Unification, 1979).

Board of National Unification, Nambukhan Yŏnghwa mit Mudae Yesul Pigyo (A Comparison of North-South Korean Films and Theatre Arts) (Seoul, Board of National Unification, 1986).

Board of National Unification, Pukhan, T'ongil Yŏngu Nonmunjip (Collection of Essays on North Korea and Korean Unification) (Seoul, Board of National Unification, 1990).

Cho, Hŭimun, 'Han'guk yŏnghwa kitchŏm-e kwanhan yŏn'gu' (A study of the beginnng of Korean film), in Chŏngok Kim (ed.), Han'guk Yŏnghwa-ŭi Saeroun Palgyŏn (A New Discovery of Korean Film) (Seoul, Korean Film Academy, 1993), pp. 7-42. 
Cho, Hŭimun, 'Han'guk yŏnghwa-ŭi saengsŏng' (The development of Korean film), Korean Film Critiques, 5 (1993), 28-80.

Cho, Hŭimun, “"Han'guk yŏnghwa”-ŭi kaenyŏmjŏk chŏngŭi-wa kijŏm-e kwanhan yŏn'gu' (A study of the major concepts in Korean film and its beginning), Yŏnghwa Yŏn'gu (Film Study), 11 (1995), 7-29.

Cho, Yunje, Ch'unhyangjŏn (The Tale of Ch'unhyang) (Seoul, Ülyumunhwasa, 1983).

Ch'oe, Chinyong, and others (eds), Han'guk Yŏnghwa Chŏngch'aek-ŭi Hŭrŭmgwa Saeroun Chŏnmang (The Trends and the New Perspective of Korean Film Policy) (Seoul, Chimmundang, 1994).

Ch'oe, Ch'ǒkho, Pukhan Yesul Yŏnghwa (North Korean Art Film) (Seoul, Sin won Munhwasa, 1989).

Ch'oe, Ch’ŏl, and Sŏnggyŏng Sol (eds), Sŏlhwa, Sosŏl-ŭi Yŏn'gu (A Study of the Myth and the Novel) (Seoul, Chŏngŭmsa, 1984).

Ch'oe, Chunghwi, and Hoyun Li (eds), Chosŏn Yŏnghwa Yon'gam (Korean Film Yearbook) (P'yŏngyang, Munye Publishing House, 1987).

Ch'oe, Changjip, 'Minjujuŭiro-ŭi ihaeng-gwa nodong undong' (Transition to democracy and labour movement), in Chang, Ǔlbyŏng, and others, Nambukhan Chŏngch'ï-ŭi Kujo-wa Chŏngmang (The Structures and Prospects of North and South Korean Politics) (Seoul, Hanul Academy, 1994), pp. 136-70.

Ch'oe, Ǔnhŭi, and Sangok Shin, Kim Jong II Wangguk 1 \& 2 (The Kingdom of Kim Jong II 1) (Seoul, Dong-A Ilbo, 1988).

Ch'oe, Yŏngch'ŏl, lije shingmin ch'iha-ŭi yŏnghwa chŏngch'aek' (Film policies under the Japanese colonial rule), in Yi, Chunggŏ, and others, Han'guk Yŏnghwa-ŭi Ihae: Arirang-esŏbut'ŏ Ǔnma-nŭn Tolaoji Annŭndakkaji (Understanding Korean Films: From Arirang to Silver Stallion) (Seoul, Yeni, 1992), pp. 217-42.

Chŏn, Kwangyŏng, Shin Sosŏl Yŏrigu (A Study of the New Novel) (Seoul, Saemunsa, 1986).

Chŏn, Yangjun, and Hyoin Yi, and Chŏngha Yi (eds), Redigo 2 Chip: Saeroun Han'guk Yŏnghwa-rŭl Wihayŏ (Ready Go 2: For the New Korean Film) (Seoul, Iron-gwa Shilch'ŏn, 1988).

Chŏn, Yangjun, and Kich'ŏl Chang (eds), Tatchin Hyŏnshil, Yŏllin Yŏnghwa: Yu Hyŏnmok Kamdok Chakp'umjip (Closed Reality, Open Film, The Works of Yu Hyŏnmok, the Director) (Seoul, Che 3 Munhaksa, 1992).

Chŏng, Sŏngmu, Shidae-wa Munhak Yesul-ŭi Hyŏngt'ae (An Era and the Form of Literature and Art) (P'yŏngyang, Social Science Publishing House, 1987).

Chosŏn Chungang (ed.), Chosŏn Chungang Yŏn'gam 1988 (Chosŏn Chungang Year Book 1988) (P'yŏngyang, Chosŏn Chungang T'ongshinsa, 1988).

Cultural Development Research Institute, Munhwa Yesul Tonggye Charyojip (Collection of Culture and Art Static Data) (Seoul, Korean Culture and Arts Foundation, 1989).

Cultural Development Research Institute, Han'guk-ŭi Munhwa Yesul Hyangsu Shilt'ae-wa Chŏngch'aek Taeŭng Pangan (The Actual Conditions of Enjoyment of Korean Culture and Art and the Corresponding Policy) (Seoul, Korean Culture and Art Foundation, 1989). 
Cultural Planning Committee, Che 7 ch'a 5 Kaenyŏn Kyehoek: Munhwa Pumun Kyehoekan (The Seventh Five-year Program, The Cultural Plan) (Seoul, Ministry of Culture, 1991).

Han, Chŭngmo, and Sŏngmu Chŏng, Juche-ŭi Munye Iron Yŏn'gu (A Study on the Juche Theory of Literature and Art) (P'yŏngyang, Social Science Publishing House, 1983).

Ho, Ch'ang, 'Yŏnghwa sŏngjang karomangnŭn kŏmyŏl chedo' (The censorship that hinders the growth of film), Korean Film Critiques, 8 (1996), 209-18.

Hwang, Hyŏnt'ak, Han'guk Yŏngsang Sanŏmnon (A Study of the Korean Visual Media Industry) (Seoul, Nanam, 1995).

Kang, Hyŏndu, Pukhan Mass Mediaron (A Study of North Korean Mass Media) (Seoul, Nanam, 1997).

Kim Chaeyong, Pukhan Munhak-üi Ihae (Understanding of North Korean Literature) (Seoul, Munhak-kwa Chisŏngsa, 1994).

Kim, Chisŏk, and others, Han'guk Yŏnghwa Ilkki-ŭi Chŭlgŏum (The Pleasure of Reading Korean Film) (Seoul, Ch'aek-kwa Mŏngsang, 1995).

Kim, Chŏngok (ed.), Han'guk Yŏnghwa-ŭi Saeroun Palgyŏn (A New Discovery of Korean Film) (Seoul, Korean Film Academy, 1993).

Kim, Chongwŏn, 'Ch'och'anggi Han'guk yŏnghwasa kisul-ŭi munjejŏmgwa saeroun kijŏm-ŭi cheshi' (The problems of describing the early Korean film history and a redefinition of the beginning of Korean film), Korean Film Critiques, 5 (1993), 11-28.

Kim, Ch’unt'aek, Orinara Kojŏn Sosŏlsa (A History of Korean Classical Narratives) (Seoul, Han'gilsa, 1993).

Kim, Dong-Uk, Ch'unhyangjŏn Yŏn'gu (A Study of Ch'unhyangjŏn) (Seoul, Yonsei University Press, 1985).

Kim, II Sung, Kim II Sung Chǒjak Sŏnjip 1 (Selected Works of Kim II Sung

1) (P'yongyang, Korean Workers' Party Publishing House, 1967).

Kim, II Sung, Kim II Sung Chǒjak Sŏnjip 2 (Selected Works of Kim II Sung

2) (P'yongyang, Korean Workers' Party Publishing House, 1968).

Kim, II Sung, Kim II Sung Chǒjak Sŏnjip 4 (Selected Works of Kim II Sung

4) (P'yongyang, Korean Workers' Party Publishing House, 1968).

Kim, II Sung, Kim II Sung Chǒjak Sŏnjip 5 (Selected Works of Kim II Sung

5) (P'yongyang, Korean Workers' Party Publishing House, 1972).

Kim, II Sung, Kim II Sung Chŏjak Sŏnjip 6 (Selected Works of Kim II Sung

6) (P'yongyang, Korean Workers' Party Publishing House, 1974).

Kim, II Sung, Kim II Sung Chǒjak Sŏnjip 3 (Selected Works of Kim II Sung

3) (P'yongyang, Korean Workers' Party Publishing House, 1975).

Kim, II Sung, 'Yŏngha-nŭn hososŏng-i nopaya hamyŏ hyŏnshil-boda apsŏ nagaya handa' (Film should strongly appeal to the masses and advance them more than reality) (17 January 1958), in Kim II Sung Chŏjak Sŏnjip 12 (P'yongyang: Korean Workers' Party Publishing House, 1981), pp. 5-13.

Kim, II Sung, 'Hyŏngmyŏngjŏk munhak yesul-ul ch'angjakhalde daehayŏ' (Concerning the creation of revolutionary literary art) (7 November 1964), in Kim II Sung Chŏjak Sŏnjip 18 (P'yongyang, Korean Workers' Party Publishing House, 1982), pp. 436-8. 
Kim, II Sung, 'Hyŏngmyŏng chuje chakp'um-esoŭi myŏt kaji sasang mihakchŏk munje' (Some ideological and aesthetic problems in revolutionary works) (10 January 1967), in Kim II Sung Chǒjak Sŏnjip 21 (P'yongyang, Korean Workers' Party Publishing House, 1983), pp. 13-28.

Kim, II Sung, Kim II Sung Chŏjak Sŏnjip 9 (Selected Works of Kim II Sung 9) (P'yongyang, Korean Workers' Party Publishing House, 1987).

Kim, Jong II, Yŏnghwa Yesulron (The Theory of Cinematic Art) (P'yongyang, Korean Workers' Party Publishing House, 1973).

Kim, Jong II, Juche Hyŏngmyŏng-ŭi Uiŏp-ŭl Wansŏng-ŭl Wihayo 2 (19721973) (For Accomplishing the Great Achievement of Juche Revolution 2) (P'yongyang, Korean Workers' Party Publishing House, 1987).

Kim, Jong II, Kim Jong II Chŏjaksŏn (Selected Works of Kim Jong II), ed. Kyŏngnam University Far-East Research Institute (Seoul, Kyŏngnam University Far-East Research Institute, 1991).

Kim, Jong II, 'Sahoejuŭi kŏnsŏl-esŏ kun-ŭi wich'i-wa yŏkhal' (The army's position and role in the socialist reconstruction), in Kyŏngnam University Far-East Research Institute (ed.), Kim Jong II Chŏjaksŏn (Selected Works of Kim Jong II) (Seoul, Kyŏngnam University Far-East Research Institute, 1991), pp. 1-34.

Kim, Jong II, 'Marx-Leninjuŭi-wa Juche sasang-ŭi kich'i-rŭl nop'i tŭlgo naagaja' (Let us move forward with Marxism-Leninism and Juche Idea) in Kyŏngnam University Far-East Research Institute (ed.), Kim Jong II Chǒjaksŏn (Selected Works of Kim Jong II) (Seoul, Kyŏngnam University Far-East Research Institute, 1991), pp. 163-86.

Kim Jong II, Kim Jong II Chǒjak Sŏnjip 1 (P’yŏngyang, Korean Workers' Party Publishing House, 1992).

Kim Jong II, 'Saeroun hyŏngmyŏng munhak-ŭl kŏnsŏlhalde daehayŏ' (Concerning the creation of the new revolutionary literary art) (7 February 1966), in Kim Jong II Chŏjak Sŏnjip I (P’yŏngyang, Korean Workers' Party Publishing House, 1992), pp. 113-14.

Kim Jong II, 'Pandang panghyŏngmyŏng punjadŭl-ŭi sasang yŏdok-ŭl ppurippaego tang-ŭi Yuil sasang ch'egye-rŭl seulde daehayŏ' (Concerning the eradication of the poisonous thoughts of the anti-party, anti-revolutionary elements and the establishment of Yuil thought) (25 June 1967), in Kim Jong II Chŏjak Sŏnjip I (P'yŏngyang, Korean Workers' Party Publishing House, 1992), pp. 230-1.

Kim Jong II, ‘Tabujak yesul yŏnghwa Minjok-kwa Unmyŏng-ŭi ch'angjak sŏnggwa-e t'odaehayŏ munhak yesul kŏnsŏl-esŏ saeroun chŏnhwan-ŭl ilŭk'ija' (Let's reach a new turning point in the construction of literature and art, based on the creative result of the multi-volume art film The Nation and Destiny) (23 May 1992) in Chosŏn Chungang Nyŏn'gam 1993 (Chosŏn Year Book 1993) (P'yŏngyang, Chosŏn Changang T'ongshinsa, 1993), p. 50.

Kim, Sunam, Han'guk Yŏnghwa Chakka Yŏn'gu (A Study of Korean Film Directors) (Seoul, Yeni, 1995).

Kim, Sunam, 'Yun Paengnam-ŭi yŏnghwa insaeng yŏn'gu' (A study of Yun Paeknam's film and life), in Han'guk Yǒnghwa Chakka Yŏn'gu (A Study of Korean Film Directors) (Seoul, Yeni, 1995), pp. 37-62. 
Kim, Sunam, 'Na Un'gyu-ŭi minjok yŏnghwa chaego' (Reconsideration of the nationalistic film of Na Un'gyu), in Han'guk Yŏnghwa Chakka Yŏn'gu (A Study of Korean Film Directors) (Seoul, Yeni, 1995), pp. 63-90.

Kim, Sunam, 'Mise-en-scène yŏnghwa-ŭi taega Shin Sangok' (Shin Sangok, the master of Mise-en-scène), in Han'guk Yŏnghwa Chakka Yŏn'gu (A Study of Korean Film Directors) (Seoul, Yeni, 1995), pp. 191-227.

Kim, Sunam, 'Han'guk yŏnghwa-ŭi chaengjŏm-gwa kŭ pansŏng' (A reflection of the issues of Korean film), Korean Film Critiques, 8 (1996), 219-28.

Korean Cinema Critics League, Yŏnghwa P'yŏngron 2 (Korea Cinema Critic 2) (Seoul, Wŏnbanggak, 1990).

Korean Association of Professors of Film Studies (ed.), Yŏnghwa-ran Muŏshin'ga (What is Cinema?) (Seoul, Chishik Sanŏpsa, 1994).

Korean Motion Pictures Promotion Corp. (ed.), Han'guk Yŏnghwa 70 Nyŏn Taep'yojak 200 Son (Seventy Years of Korean Filmdom) (Seoul, Tongmyŏng Print, 1989).

Korean Motion Pictures Promotion Corp. (ed.), Han'guk Yŏnghwa Yŏn'gam (Korean Film Year Book) (Seoul, Tongmyŏng Print, 1990).

Kwŏn, Yŏngmin, and others, Pukhan Munhwa Yesul Yŏn'gu-ŭi Panghyang (A Direction of Study on North Korean Culture and Art) (Seoul, The Korean Culture Art Foundation, 1990).

Kyŏngnam University Far-East Research Institute (ed.), Pundan Pansegi Nambukhan-ŭi Sahoe-wa Munhwa (Half a Century of North and South Korean Societies and Cultures) (Seoul, Kyŏngnam University Far-East Research Institute, 1996).

Linguistics Research Institute of Social Science Board (ed.), Munhak Yesul Sajon (Literature and Art Dictionary) (P'yŏngyang, Social Science Publishing House, 1972).

Literature Research Institute of Social Science Board (ed.), Juche Sasang-e Kich'ohan Munye Iron (The /i/che-Oriented Theory on Literature and Art) (P'yŏngyang, Social Science Publishing House, 1975).

Min, Pyŏngnok, 'Saeroun Han'guk yŏnghwa sanop-e taehan koch'al' (An examination of the new Korean film industry), in Chŏngok Kim (ed.), Han'guk Yŏnghwa-ŭi Saeroun Palgyŏn (A New Discovery of Korean Film) (Seoul, Korean Film Academy, 1993), pp. 191-224.

Ministry of Culture and Information, Haengjŏng Paeksŏ (An Administrative White Paper) (Seoul, Ministry of Culture and Information, 1976).

Ministry of Culture and Information, Haengjŏng Paeksŏ (An Administrative White Paper) (Seoul, Ministry of Culture and Information, 1986).

National Film Research Institute (ed.), Minjok Yŏnghwa 1 (National Film 1) (Seoul, Ch'in'gu, 1989).

National Film Research Institute (ed.), Minjok Yŏnghwa 2 (National Film 2) (Seoul, Ch'in'gu, 1990).

National Film Research Institute, 'P'aŏp Chŏnya-ŭi sŏnggong-gwa kŭ p'yŏngga' (The fruits of The Night before the Strike and an evaluation) in National Film Research Institute (ed.), Minjok Yŏnghwa 2 (National Film 2) (Seoul, Ch'in'gu, 1990), pp. 173-205.

North Korea Research Institute (ed.), Pukhan Ch'ongnam (A Survey of North Korea) (Seoul, North Korea Research Institute, 1980). 
Paek, Chihan (ed.), Pukhan Yŏnghwa-ŭi Ihae (Understanding North Korean Film) (Pusan, Ch'in'gu, 1989).

Pak, Hyŏnch'ae, and Ch'angryŏl Chŏng (eds), Han'guk Minjokchuŭiron 3 (Korean Nationalism 3) (Seoul, Ch'angjak-kwa Pip'yŏngsa, 1985).

Pak, Myŏngjin, 'Pukhan yŏnghwa-ŭi t'ŭksŏng-gwa kŭ shilt'ae (The characteristics and reality of North Korean film), in Cultural Development Institute (ed.), Pukhan Munhwa Yesul Yŏn'gu-ŭi Panghyang (The Direction of North Korean Culture and Art) (Seoul, Korean Culture and Art Foundation, 1990), pp. 357-412.

Pyŏn, Inshik, 'Inbonjuŭi-ranŭn kitpal innŭn kisu Im Kwŏnt'aek' (Im Kwŏnt'aek, the banner bearer with the flag called humanism), Korean Film Critiques, 6 (1994), 73-88.

Pyŏn, Chaeran, '1930 nyŏndae chŏnhu KAPF yŏnghwa hwaldong yŏn'gu' (A study of the KAPF film movement in the late 1920s and the early 1930s) in National Film Research Institute (ed.), Minjok Yŏnghwa 2 (National Film 2) (Seoul, Ch’in'gu, 1990), pp. 219.

Seoul Film Group, Saeroun Yŏnghwa-rŭl Wihayŏ (For the New Korean Film) (Seoul, Hangminsa, 1983).

Shim, Chiyŏn, Haebang Chŏngguk Nonjaengsa 1 (The History of Debates on the Post-Liberation 1) (Seoul, Hanul, 1986).

So, Yŏnho, and Kangryŏl Yi, Pukhan-ŭi Kongyŏn Yesul 1 (North Korean Performance Art 1) (Seoul, Koryǒwŏn, 1990).

Social Science Publishing House (ed.), Munhwa Yesul Chakp'um-ŭi Chongja e Kwanhan Iron (A Theory on the Seed of Literature and Art Works) (P'yŏngyang, Social Science Publishing House, 1977).

Social Science Publishing House (ed.), 'Kyoyuk-kwa Munhak Yesul-ŭn Saramdŭl-ŭi Hyŏngmyŏngjŏk Segyegwan-ŭl Seunŭn te Ibajihayŏya Handa'-e Taehayŏ (About 'Education and Literature-Art Should Serve to Teach People the Revolutionary World of View') (P'yŏngyang, Social Science Publishing House, 1974).

Social Science Publishing House (ed.), Uri Tang-ŭi Munye Chŏngch'aek (Our Party's Policy of Literature and Art) (P'yŏngyang, Social Science Publishing House, 1973).

Sol, Sŏnggyŏng, Ch'unhyangjŏn Hyŏngsŏng-gwa Kyet'ong (The Development and Classification of Ch'unhyangjŏn) (Seoul, Chŏngŭmsa, 1986).

Son, Hoch'ŏl, and others, Hariguk Chŏnjaeng-gwa Nambukhan Sahoe ŭi Kujojŏk Pyŏnhwa (The Korean War and the Structural Changes of South and North Korean Society) (Seoul, Kyŏngnam University Far-East Research Institute, 1991).

So Chaejin, Pukhan Sahoe-ǔi Kyegupkaldŭng Yŏn'gu (A Study of Class Conflict in North Korea) (Seoul, National Unification Institute, 1996).

Three Years After Liberation Research Group of History Problem Research Institute, Haebang 3 Nyŏnsa Yŏn'gu Immun (An Introduction to Study Three Years After Liberation) (Seoul, Kkach'i, 1989).

Unification Problem Research Institute (ed.), Pukhan Kyŏngje Charyojip: Pukhan Sahoejuйi Shilch'e-wa Iron (A Collection of North Korean Economic Data: The Facts and Theory of North Korean Socialist Economy) (Seoul, Minjok T'ongil, 1989). 
Yi, Chŏngha, Tak Kwangsu interview', in Hyoin Yi (ed.), Han'guk-ui Yonghwa Kamdok 13 In (Thirteen Korean Film Directors) (Seoul, Yŏllin Ch'aektúl, 1994), pp. 239-50.

Yi, Chunggŏ, 'Han'guk yŏnghwasa' (Korean film history), in the Korean Association of Professors of Film Studies (ed.), Yŏnghwa-ran Muŏsh-in'ga (What is Cinema?) (Seoul, Chishik Sanŏpsa, 1986), pp. 183-210.

Yi, Chunggŏ, 'Han'guk yŏnghwasa yŏn'gu' (A study of Korean film history), in Yi, Chunggŏ et al, Han'guk Yŏnghwa-ŭi lhae: Arirang-esofruí'o Ǔnmanŭn Tolaoji Annŏnda-kfazjï (Understanding Korean Films: From Arirang to Silver Stallion) (Seoul, Yeni, 1992), pp. 13-70.

Yi, Chunggŏ, 'lije shidae uri yŏnghwa' (Our film in the Japanese colonial period), in Yi, Chunggŏ et al, Han'guk Yŏnghwa-ŭi Ihae: Arirang-esŏbut'ŏ Ǔnmanŭn Tolaoji Annŭnda-ktaiji (Understanding Korean Films: From Arirang to Silver Stallion) (Seoul, Yeni, 1992), pp. 139-54.

Yi, Hyoin, Han'guk Yŏnghwa Yŏksa Kangŭi 1 (Lecture on Korean Film History 1) (Seoul, Iron-gwa shilch'ŏn, 1992).

Yi, Hyoin, 'Haebang chikhu Han'guk yŏnghwagye-ŭi yŏnghwa undong' (The film movement in post-Liberation period), Korean Film Critiques, 5 (1993), 81-96.

Yi, Hyoin, Han'guk-ŭi Yŏnghwa Kamdok 13 In (Thirteen Korean Film Directors) (Seoul, Yollin Ch'aektúl, 1994).

Yi, Onjuk, Pukhansahoe Yŏn'gu: Sahoehakchŏk Chŏpkŭn (A Study on North Korea, Sociological Approach) (Seoul, Seoul University Press, 1989).

Yi Sŏngdŏk, 'Rodong kyegŭp-ŭi saenghwal ch'ŏlhak-ŭl kuhyŏnhan segyejŏkin kŏljak (1)' (The world's great work materialising the philosophy of life of the working class), Chosŏn Yŏngha (Chosŏn Film), 267 (September 1995), p. 40.

Yi, Uyŏng, Nambukhan Munhwa Chŏngch'aek Pigyo Yŏn'gu (A Comparative Study of North and South Korean Culture Policies) (Seoul, the Research Institute for National Unification, 1994).

Yi, Uyŏng, Kim Jong II Munye Chŏngch'aek-ŭi Chisok-kwa Pyŏnhwa (The Continuity and Changes of Kim Jong Il's Literature and Art Policy) (Seoul, the Research Institute for National Unification, 1997).

Yi, Uyŏng, 'Pukhan yŏnghwa-e pich'in Kim Jong II ch'osang' (A portrait of Kim Jong II as reflected in North Korean film), Shin Dong-A, September 1994, 252-65.

Yu, Ch'ijin, 'Ch'unhyangjŏn kaksaek-e kwanhayŏ' (About adaptation of Ch'unhyangjŏn), in Ch'ŏl Ch'oe and Sŏnggyŏng Sol (eds), Sŏlhwa, Sosŏl-ŭi Yŏn'gu (A Study of Myth and Novel) (Seoul, Chŏngŭmsa, 1984), pp. 205-7.

Yu, Hyŏnmok, Hariguk Yŏnghwa Paldalsa (Korean Film History) (Seoul, Hanjin, 1980).

Yun, Tŏkhŭi, and Kim Tot'ae, Nambukhan Sahoe Munhwa Kongdongch'e Hyŏngsŏng Pangan (Towards Formation of the North and South Korean Social, Cultural Community) (Seoul, the Research Institute for National Unification, 1992). 